\title{
Germany refuses to prolong university support scheme
}

Munich. Germany's federal government last week announced that it will not extend a programme set up six years ago to help universities through an overcrowding crisis generated by the 'baby boom' of the 1960s.

But the announcement has prompted an angry reaction from the University Rectors Conference (HRK). By abandoning the programme, says the HRK, the government could be responsible for the loss of thousands of university jobs at a time when student numbers are rising at a record rate.

Germany's post-war constitution gives full responsibility for education to the Länder, to avoid an excessive concentration of power over education. Nevertheless, the federal government contributes half of universities' building costs, and provides much of the support for university research.

The system worked well until massive rises in student numbers, combined with the more recent recession, put an increasing strain on resources. Overcrowded classrooms have resulted primarily from a constitutional right guaranteeing a university education to all students with the school leaving certificate, the Abitur.

The federal government believes that universities should help themselves by compromising on this right and restricting student numbers in over-subscribed subjects. It has, however, been willing to help them meet the impact of the baby boom. to provide financing towards a DM2.1-billion programme to ease the pressure of student numbers in heavily subscribed subjects such as informatics. Known as the first Hochschulsonderprogramm (HSP1), this created 3,200 positions nationwide, but runs out at the end of this year.

The HSP1 was supplemented in 1991 by an additional 10-year DM4-billion programme, HSP2, which had four broad aims: to create new positions for women, for young scientists, and within the technically orientated institutes of higher education (Fachhochschulen), and to support European collaboration in the universities. The 60 per cent federal share of HSP2 funding is
In the late 1980 s, the government agreed

higher than in HSP1, where financing was balanced equally with the Länder.

Both programmes support only west German universities, and a third, DM2.4-billion programme (HEP) was therefore set up for eastern German universities. Because of their special problems, the federal government paid three-quarters of this bill.

The federal and Länder governments have now agreed that the HSP2 and HEP programmes should be extended beyond 1996, so that general trends - such as the continuing low number of women in academic life - can be influenced centrally.

They also agree that the two programmes should be merged. How costs will be shared is not yet known, but the Länder will probably challenge the federal government's suggestion of a 50:50 split.

More controversially, the federal government is to abandon the HSP1. "The federal government will not allow any claims in areas in which the Länder carry the responsibility, be it political or financial", says Berndt Neumann, parliamentary secretary of state for education and research. Curricula come into this category, he argues.

In a statement two weeks ago, Neumann pointed out that the Länder had not made any efforts to reduce student numbers by introducing limits, despite agreeing two years ago to consider such a move.

The universities see the federal government's attitude as potentially damaging. Gerhard Neuweiler, professor of zoology at the Technical University in Munich and a former head of the German science council, the Wissenschaftsrat, says that as the government sets national priorities in science, such as informatics, it must help foot the bill because most Länder cannot afford to.

Disillusion is widespread in universities. Last month, Adolf Theis resigned as rector of the University of Tübingen in protest at the lack of support by the federal government for universities. If this does not change, he warns, politicians will face serious conflict. "Tensions among students is rising in a manner reminiscent of 1968.'

Alison Abbott

\section{CERN makes good on technician's sabotage}

London. The Large Electron Positron Collider (LEP) at the European Laboratory for Particle Physics (CERN) was switched on again last week after a four-month maintenance shut-down - despite the sabotage in February of two of its particle accelerators.

Fears were raised over the loss of laboratory time following the discovery on 13 February that one of CERN's long-serving technicians had cut about 200 cables and NATURE * VOL 375 - 11 MAY 1995 engineers had worked "flat out" to put right the damage caused.

\section{UNCTAD to help former Soviet scientists prosper}

London. The United Nations agency responsible for trade issues is to set up a special programme to help scientists in the former Soviet republics to negotiate with foreign companies interested in licensing their research results.

The programme, to be launched by the United Nations Conference on Trade and Development (UNCTAD), will help research and development managers in the former republics to master international business skills and intellectual property protection.

The UNCTAD programme will be paid for from funds allocated to the agency for assistance for the states of the former Soviet Union by the United Nations Development Programme (UNDP) in New York. It was approved last week by the Commission on International Investment and Transnational Corporations.

The programme will offer technical assistance to governments to establish policies and laws supporting scientific development. It will also provide international expertise on issues such as trade legislation, how to identify potential foreign partners and negotiation skills.

UNCTAD officials claim the large amounts spent by the Soviet regime on science have produced valuable resources which, if tapped properly, could generate a significant income for the republics.

But at present, they say, many risk losing their scientific and technological resources as their nascent market economies do not have the marketing skills to make the best use of this investment. The UNCTAD programme aims to help halt this decline by offering a structure for marketing such scientific resources internationally.

Maurice Odile, a spokesman for UNCTAD, says that one of the difficulties is that many scientists are unaware of the potential value of their intellectual property, or how either to ensure its protection or to market it. Yet without such knowledge, UNCTAD fears that such scientists risk being exploited by foreign corporations

Scientists previously operated in the security of the Soviet system which provided intellectual property protection by issuing so-called 'authors' certificates' of relatively low value, with the results becoming the property of the state.

With the collapse of communism, the flow of funding for science has slowed to a trickle in most of the former republics. UNCTAD started assisting countries such as Belarus, Estonia, Latvia, Lithuania, Ukraine and Uzbekistan in 1992, helping them to make strategic alliances and business deals with corporations.

Peter O'Neill 